\title{
Students' Perceptions: Bilingual Language Used in EFL Classroom
}

\author{
Aulia Larasati, Yoga Prihatin*, H. Sumartono
}

\author{
English Education Department, Universitas Pancasakti Tegal, Indonesia \\ *Corresponding author. Email: yogaprihatin92@gmail.com
}

\begin{abstract}
The purpose of this study is to ascertain students' perceptions of teachers' use of bilingual language in English language instruction in the classroom. This study employs a qualitative approach as the foundation for its research. The study enrolled 241 students in grades 11 at SMA N 5 Tegal. The data collection techniques used are the Lickert Scale Questionnaire and Semi-structured Interview. There are ten questionnaire questions and three interview questions regarding students' perceptions of teachers' use of bilingual language. The interviewees are only thirty students chosen at random from eight classes. This study reveals that 96 percent of 241 students have a favorable attitude toward the use of bilingual language. However, $4 \%$ of students oppose the use of the bilingual language. Hopefully, these findings will contribute to a more informed choice of language instruction.
\end{abstract}

Keywords: Bilingualism, Students' Perception, EFL Classroom

\section{INTRODUCTION}

\subsection{Bilingualism}

Bilingualism is someone who uses and speaks in two languages. Bloomfield [1] stated that bilingualism as someone which controls two languages like a native speaker [2]. Adapted from Grosjean's theory [3] is that bilingualism is the fact the use of two languages regularly [4]. Haugen [5] says that bilingualism is starting when a speaker mastery the ability to create meaningful statements in two languages. Bilingual can be learned, but the experience is also important. Bilingual can be achieved for anyone who has achieved a state of fluency in two languages. To teach bilingualism is important for children because it can affect cognitive development. Bilingualism is an individual who is skilled in each language. Hammer [6] \& Malakoff [7] stated that bilingualism appears positive cognitive development in children, especially when both languages are supported in their society and their school.

In the Education world, bilingualism is called bilingual approach. The bilingual approach is frequently used to refer to the use of the students' native language (L1) in order to learn the target language (in this case is English). Indeed, teachers employ the bilingual approach as a means of instructing students or as a tool for learning English. Thus, the bilingual approach utilizes two or more languages in the classroom as a medium for learning a second or foreign language when used in a class with students who speak a similar language. Three reasons why a bilingual approach may be beneficial in classroom learning activities are as follows: Tsukamoto[8] To maintain a pleasant classroom environment, to foster students' comprehension, and to maximize class time. Additionally, Polio and Duff [9] note that the use of L1 may be beneficial for establishing a relaxing atmosphere in the classroom. [8]. Because if the teachers used an English only approach for their classes, the students will feel burdened and result in the decline of students' will in learning English. Just like what Burden [10] do in his classes. He used "English only approach" but the result is the students feel stressed. The preceding definition of a bilingual framework is based on the context of Indonesia, where English is both a different language and a topic for students.. In Indonesia, the term "bilingual" refers to the practice of foreign language acquisition through use of students' native tongue.

\subsection{Students' Perception}

The term "perception" derives from the Latin word percipio, which means "receiving, collecting.", and understanding with mind or sense and action of taking 
ownership [11]. Perception is a perception based on a person's thinking, or according to what a person sees.

Perception can be concluded based on what we see, feel, hear and also through body language. Similarly to how perception is defined as the process of gathering information through body language, sensory receptors are converted into perceptions about what we think, observe, notice, taste, feel, and contact.[12].

From the argument above we can see that perception is defined as the process of gathering information through our senses of sight, hearing, smell, taste, and touch. That means perception is involved in our five senses. There are two aspects of perception that has a role in affecting someone's perception. These aspects are Cognitive and Psychology. According to Harnad [13], perception has two facets. These two aspects are cognitive and psycholog [14]. The cognitive aspect is one that emphasizes comprehension and meaning; it encompasses justification, argumentation, rationality, and perception. These facets are visible when the effects of emotions, personal knowledge, and cognition are examined. on comprehension and response. The second aspect is psychology, which focuses on the relationship between experiences and how they affect the outcome of perception. Individuals' perceptions can be influenced by a variety of internal and external factors. Internal factors such as physiological, intellectual, inspirational, impactful, and selective attention factors indicate that if their perspective from low-motivation individuals can be effected by greater motivation of individuals, this can be a beneficial condition, but would be detrimental if the converse were true.[14]. On the other hand, external factors include stimuli, the surroundings, heritage, and faith. That is, if some people live in a healthy environment, their perceptions of that surroundings may be influenced, or if people from different cultures influence one another's perceptions of something. Both of these factors may be beneficial, but they may also be detrimental, depending on our perspective.

For students, perception can make them say what they need and what they have an opinion about the method that the teachers use in class. It also can help the teacher to understand what the student need. Just like what already been mention above about perception, students' perception can be taken by using a questionnaire or interviewing. In the educational world students' perception is also important. By perception, the students can be allowed to gives some complaint to the teacher method use, or they can give some solution to what they need to their teacher. So the teacher can be more understand and can choose the right method to teach the students. Without students' perception the teacher will not know what they think about them, did they understand when they teach them, and the teacher can't see they self in students point of view. Luyten et al [15] and Kanselarr G et al [16] stated that in the teaching and learning environment the students have their perceptions.[17]

\subsection{EFL Classroom}

In Indonesia, English is classified as a Foreign Language or English as a Foreign Language (EFL). Once students are taught English in their schools or during classroom process but try to speak their mother tongue language outside of class, this is referred to as an EFL situation. This is referred to as English language learning in a country where English is not spoken. The use of L1 is generally discouraged in EFL classrooms. Since the late 18th century, English has been taught using a method derived from monolingualism, including the direct method, audiolingual instruction, communicative language instruction, and assignment instruction. [18]

Nunan and Lamb (1996) stated that avoiding the use of L1 during the English language learning process is nearly impossible. [19] Teachers who share the same L1 as their students are more likely to use it in their classes. [19] Nevertheless, some teachers who teach in L1 frequently feel guilty. EFL students exhibited a favorable attitude toward the addition of L1 to their L2 classes, as a result of their demographic characteristics. [20, There are seven functions of incorporating students' L1 into EFL classroom instruction.

a. Preventing waste of time

b. Pointed out the problem areas out

c. Increase students' comprehension by allowing them to respond in their native language.

d. Make it easier for the teacher to explain something to the students

e. Assisting students and teachers with difficult vocabulary or rephrasing.

f. Assisting students in checking their comprehension when the teacher does not speak in their native language.

g. It can be beneficial for students who need to combine the two languages for purposes such as interpreting.

\section{RESEARCH METHODOLOGY}

This is a qualitative study that investigates students' perceptions of teachers' use of Bilingual Language in EFL classrooms. The respondents to the study are 241 students from eight 11th grade classes at SMA N 5 Tegal. The data collecting techniques are Questionnaire of Lickert Scale [19] and Semistructured Interview by Freankel and Wallen (2012). There are 10 questionnaire questions and 3 questions 
of the interview. The interview respondents are only 30 students taken from 8 classes randomly.

The researcher creates 12 questions and distributes them to a non-sample class. Thus, after obtaining the results, the researcher uses SPSS to determine the questionnaire's validity. This check verifies that the questions are valid and appropriate for distribution pertaining to the sample-classes. Finally, the researcher interviews respondents to ascertain students' perceptions of teachers' bilingual language use in EFL classrooms.

\section{RESEARCH FINDINGS AND DISCUSSION}

The research had been started from May $28^{\text {th }}$ until June $17^{\text {th }}, 2019$ in eight days to all students of $11^{\text {th }}$ grades of SMA N 5 Tegal. In this research, the materials made based on the function of Bilingual language and also based on Yusi Nursanti and Mizuka Tsukamoto journals.

Correlation product moments are used to determine the validity of twelve questions in SPSS. Valid questions have positive validating approval values (Pearson correlation), a probability value of [sig. (2tailed)] 0.05 , and a reliable value of 0.6 or greater. The results indicate that question 6 has a [sig. (2-tailed)] of 0.499 and question 11 has a [sig. (2-tailed)] of 0,062 .

Table 1. The validity and reliability of the data were determined using SPSS.

\begin{tabular}{|lcc|}
\hline & Sig (2-tailed) & $\begin{array}{c}\text { Pearson } \\
\text { Correlation }\end{array}$ \\
\hline Learning Atmosphere & 0.000 & 0,803 \\
Comparison & 0.000 & 0.889 \\
Effectiveness & 0.000 & 0.855 \\
Benefits & 0.000 & 0.709 \\
Students' Motivation & 0.000 & 0.820 \\
Students understanding & 0.164 & 0.300 \\
Speaking ability & 0.000 & 0.771 \\
Purpose & 0.003 & 0.708 \\
Students confidence & 0.000 & 0.744 \\
Writing ability & 0.000 & 0.730 \\
Language instructions & 0.062 & 0.394 \\
Students laziness & 0.000 & 0.730 \\
& & \\
\hline
\end{tabular}

Afterward, the The researcher asks ten valid questions of sample classes to ascertain their perceptions of teachers' use of bilingual language in EFL classrooms.

The diagram illustrates students' perceptions of their teachers' use of bilingual language in the EFL classroom. According to the diagram, the higher response level indicates both strong agreement and agreement. This indicates that $96 \%$ of students agree to use bilingual language instruction in EFL classrooms.

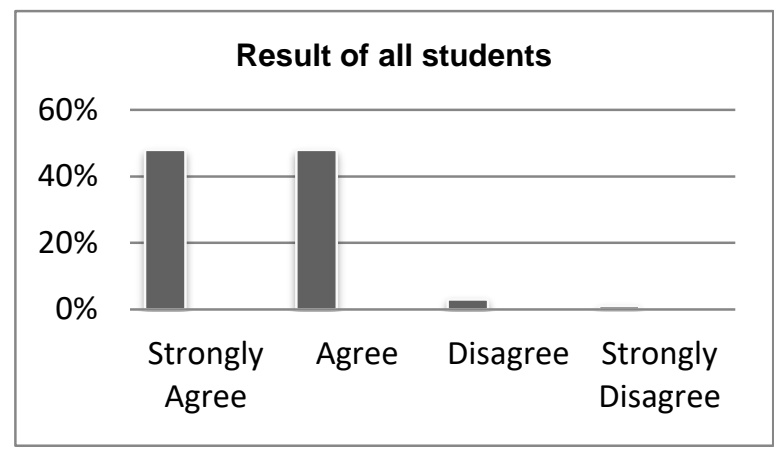

Another data collection is through the use of Freankel and Wallen's Interview of Semi-structured Interview [22]. The research presents three questions about the use of bilingual language in this study. The researcher has conducted interview data from 30 students of $11^{\text {th }}$ grades in SMA N 5 Tegal about students' opinion about the use of Bilingual language in English lesson. From 30 students as the respondents who have interviewed, the researcher conducts 5 respondents as the sample answers for this question. They are Aeni, Bayu, Febri, Rizka, Rosana.

As Bayu narrated,

"I think, the use of Bilingual languages (EnglishIndonesian) in English lessons is good to use because every student has different abilities, some are capable in English, some are not. So if the teacher only uses one language (English), students who cannot speak English will find it difficult to take lessons and understand the material that the teacher gives."

\section{As Rizka narrated,}

"In my opinion, it's good because there are a lot of students who don't understand English, especially if the teacher is not clear in explaining the material. So if the teacher uses English and Indonesian we can understand the material explained."

\section{As Rosana narrated,}

"My opinion about the use of bilingual language in English lessons is very helpful for students, because not all students can speak English and if only one language (English) is used the students cannot understand the material that the teacher explained."

Bayu, Rizka, and Rosana are agreeing that the use of Bilingual in English lesson is good, as you know every student has different abilities. Some students are proficient in English, while others are not. By utilizing bilingual language, students will have an easier time comprehending the lesson. These two students also agree that if the teachers only use one language (English) only the students who not capable in English will find it difficult to understand the materials that teachers explain. Malakoff and Hakuta [7] already 
stated in their journal that Bilingual appears positive Cognitive development in children, especially when both languages are supported in their society and their school.

As Febri narrated,

"In my opinion, the use of bilingual language in English lessons can increase students' motivation in learning English. And also make the classroom atmosphere more fun and not boring, because we also better understand the material explained."

As Aeni narrated,

"In my opinion, the use of Bilingual languages (English-Indonesian) can improve students 'abilities, increase students' willingness to learn English. So if the teacher uses Bilingual languages, children who lack English can understand the material little by little."

Both of these students agree that by use Bilingual language can help students become more motivated to learn English. Febri also added that the bilingual language made learning English not boring and made the classroom atmosphere fun. Aeni also said that if the teacher uses Bilingual language, the students who lack in English can understand the material little by little. Just like Polio [9] stated that using L1 could be beneficial for establishing a relaxing atmosphere in the classroom.[8] Because if the teachers used an English only approach for their classes, the students will feel burdened and result in the decline of students' will in learning English. Just like what Burden (2000) do in his classes. He used "English only approach" but the result is the students feel stressed.

The second interviews question is about students' choice between using Bilingual language or Monolingual language. The researcher has conducted interview data from 30 students of $11^{\text {th }}$ grades in SMA N 5 Tegal about students' opinion about the use of Bilingual language in English lesson. From 30 students as the respondents who have interviewed, the researcher conducts 5 respondents as the sample answers for this question. They are Aeni, Ali, Beti, Novi, and Tri mul.

Aeni said,

"I prefer bilingual languages because is not troublesome. So when the teacher explains the material or new vocabulary it doesn't need to bother opening the dictionary to find the meaning of the word. And using a bilingual language in learning English is also more effective and easy."

Ali said,

"I prefer to use a bilingual language because not all students can understand English and by using bilingual language students will more easily understand what the teacher explained."

Beti said,
"I, of course, prefer to use a bilingual language, because besides being more effective for me, using a bilingual language in learning English can motivate me to continue learning English."

Novi said,

"I prefer to use a bilingual language because if the teacher just using one language can make students feel bored and confuse students in understanding the material'

Tri Mul said,

"I prefer to use a bilingual language in English lessons because it is easier to understand what the teacher is saying and also the material explained by the teacher."

All of these students are choosing to use Bilingual language is used in English lessons because it is more effective and makes it easier to understand the material that teachers explain. Additionally, students are more receptive to learning new vocabularies. According to Mcgroarty in Celce [22], which is adapted from [12], "Bilingual Approach to Language Learning." Explains that a bilingual approach is used in a similar group of students to provide language instruction in two (or more) languages. As Harbord [23] previously stated, students will naturally make connections between what they are learning and their L1.

While some may believe that including L1 in classroom learning activities slows target language acquisition and is a waste of time, there must be a reason why the bilingual approach can be used in classroom learning activities. Three reasons why a bilingual approach may be beneficial for classroom learning activities are as follows: Tsukamoto [8] To foster a positive classroom environment, to aid students' comprehension, and to make the most of class time. Duff and Polio [9] also state that the use of L1 may help create a relaxing atmosphere in the classroom; Tsukamoto [8] concurs.

The last question is about students' experience of Bilingual language as language instruction in the English classroom and also the benefits of used Bilingual language as language instructions. The researcher has conducted interview data from 30 students of $11^{\text {th }}$ grades in SMA N 5 Tegal about students' opinion about the use of Bilingual language in English lesson. From 30 students as the respondents who have interviewed, the researcher conducts 5 respondents as the sample answers for this question. They are Agil, Bayu, Diana, Linda, and Yudha.

As Agil narrated,

"I think almost all material uses a bilingual language to explain it. As in the delivery of simple present tense material, the teacher will use English first to explain the material, but if there are students who do 
not understand, the teacher will use Indonesian to explain again. It makes students understand well the learning material"

As Bayu narrated,

"Almost all materials use Bilingual languages. For example, when the Present tense material is in the present tense material there is a formula when the teacher first explains this material he uses English, then if there are still those who don't understand, the teacher uses Indonesian. It helps the students to understand the materials easily"

As Linda narrated,

"Almost all material uses a bilingual language as the language of instruction in classroom learning. For example, when describing narrative text material, teachers usually use a bilingual language so students can understand the material easily."

As Yudha narrated,

"I think almost all material uses bilingual language, for example when the teacher explains new material, first the teacher explains the material using English, but if anyone doesn't understand, they will only use Indonesian."

Hamers and Blanc [20] stated in their journal that bilingual can be learned, but the experience is also important. By using Bilingual language can affect children cognitive development. All these students are said that almost in all material the teachers will use Bilingual language as language instruction. Because by using Bilingual language as language instruction it will useful and helpful for the students to understand the material especially new material that the teacher explained. Polio and Duff [9] and Tsukamoto [8] already stated that Bilingual language can make students feel relaxed in learning English.

\section{CONCLUSION}

According to the discussion above, the majority of 11th grade students at SMA N 5 Tegal agree that bilingual language instruction should be used in EFL classrooms. As evidenced by the fact that the percentage of respondents who agree (96 percent) is greater than the percentage who disagree ( 4 percent), and respondents provide positive responses.

\section{REFERENCES}

[1] Bloomfield, Holt R, Winston. Language. New York: 1993.

[2] Maftoon P. who is bilingual? 2016.

[3] Grosjean F. The bilingual individual n.d.;2:163-87.
[4] Javor R. Bilingualism , Theory of Mind and Perspective-Taking: The Effect of Early Bilingual Exposure. Psychology and Behavioral Sciences 2016;5:143-8. https://doi.org/10.11648/j.pbs.20160506.13.

[5] Haugen E. he Norwegian language in America: A study in bilingual behavior. The American Dialects of Norwegian 1953;1.

[6] Hamers JF, Blanc MH a. Bilinguality and Bilingualism Second edition. Cambridge: Cambridge University Press 2002. https://doi.org/10.1017/CB09781107415324. $\underline{004}$.

[7] Padilla A, Fairchild H, Valadez C, Malakoff M, Hakuta K. History of Language Minority Education in the United States 1990.

[8] Tsukamoto M, ツカモトミズカ, 塚本瑞香. Students' perception of teachers' language use in an EFL classroom. 大阪女学院大学紀要 2012;8:143-54.

[9] Polio CG, Duff PA. Teachers' Language Use in University Foreign Language Classrooms: A Qualitative Analysis of English and Target Language Alternation. The Modern Language Journal 1994;78:313. https://doi.org/10.2307/330110.

[10] Burden P. The Use of "Only English" in a Learner-Centred University Classroom in Japan:

Http://DxDoiOrg/101177/0033688200031001 $07 \quad 2016 ; 31: 139-49$. https://doi.org/10.1177/003368820003100107

[11] Kim T-Y, Kim Y, Kim J-Y. A Qualitative Inquiry on EFL Learning Demotivation and Resilience: A Study of Primary and Secondary EFL Students in South Korea. The AsiaPacific Education Researcher 2017;27. https://doi.org/10.1007/s40299-017-0365-y.

[12] Nursanti Y. Students 'Perception of Teacher' S Bilingual Language. Journal of English and Education 2016;4:159-76.

[13] Harnad S. Psychophysical and cognitive aspects of categorical perception: A critical overview 1987. 
[14] Nursanti Y. Students' Perception Of Teacher's Bilingual Language Use In An English Classroom. Journal of English and Education 2016;4:159-76.

[15] Luyten L, Lowyck J, Tuerlinckx F. Task perception as a mediating variable: A contribution to the validation of instructional knowledge. British Journal of Educational Psychology 2001;71:203-23. https://doi.org/10.1348/000709901158488.

[16] Kanselaar G, Wierstra R, Linden J, Lodewijks HGLC. Learning Environment Perceptions of European University Students. Learning Environments Research 1999;2. https://doi.org/10.1023/A:1009962024666.

[17] Könings K. Student perspectives on education: implications for instructional redesign 2007:256.

https://doi.org/10.1016/j.jphotochem.2011.04. 032.

[18] Alshehri E. Using Learners' First Language in EFL Classrooms. IAFOR Journal of Language Learning 2017;3:20-33.

[19] Ockert D. Substantive Scale Verification: A Likert Scale Analysis and Critique of University Student Pedagogical Activity Preferences David Ockert 2005;9:48-64.

[20] Lanvers U, Hamers J, Blanc M. Bilinguality and Bilingualism. The Modern Language Review 2001;96:1172. https://doi.org/10.2307/3735982. 